\title{
Effect of the Spin-orbit Interaction on the Electronic Band Energies in Cadmium Chalcogenides Evaluated within the HSE06-GW Approach
}

\author{
S.V. Syrotyuk*, O.P. Malyk \\ Lviv Polytechnic National University, 12, S. Bandera St., 79013 Lviv, Ukraine
}

(Received 19 March 2021; revised manuscript received 14 August 2021; published online 20 August 2021)

\begin{abstract}
The electronic energy band spectra of CdX crystals $(X=O, S, S e, T e)$ in the wurtzite phase have been calculated. We have revealed that $\mathrm{Cd} 4 d$ electrons are localized in the narrow energy intervals of the valence band. The results obtained here show that the exchange-correlation functionals developed within the LDA and GGA approaches are not applicable to the strongly correlated $4 d$ electron subsystem. Indeed, the band gap found for the CdO crystal in these approaches is $E_{g}=0$, and its values for CdS, CdSe, and CdTe materials are $1.48,0.67$, and $0.84 \mathrm{eV}$, respectively. They all are much smaller than the measured $E_{g}$ for $\mathrm{CdX}$ materials, which are 0.91, 2.5, 1.8 and $1.8 \mathrm{eV}$, respectively. We found that "GGA - Green's function" calculation scheme, which is very effective for $s$ - $p$ electron systems, did not produce successful results for CdX crystals. That is why we have chosen a combination of "hybrid functional - Green's function" approach. The $E_{g}$ values found in CdX crystals without spin-orbit interaction are $0.90,2.49,1.92$ and $2.10 \mathrm{eV}$, respectively. The spin-orbit interaction causes a negligible narrowing $\delta E_{S O}$ of the $E_{g}$ parameter in $\mathrm{CdO}$ and CdS crystals. However, in CdSe and CdTe materials, the narrowing parameter $\delta E_{\text {SO }}$ values are 0.12 and $0.27 \mathrm{eV}$, respectively. Corrected by $\delta E_{S O}$ band gaps of CdSe and CdTe crystals have the values of 1.80 and $1.83 \mathrm{eV}$, respectively. The $E_{g}$ values found here are well compared with the experiment. It is found that the energy bands of the semicore $\mathrm{Cd} 4 d$ electrons obtained without spin-orbit interaction overlap in CdX crystals. Spin-orbit interaction leads to a widening of Cd $4 d$ energy bands. Moreover, in CdSe and CdTe crystals, the spin-orbit interaction leads to a clear separation of $4 d$ electron energy bands into two parts, the lower of which contains 8 and the upper 12 branches of the spectrum.
\end{abstract}

Keywords: CdX, Wurtzite phase, HSE06, GW, Spin-orbit interaction.

DOI: 10.21272/jnep.13(4).04003

PACS numbers: 71.15.Mb, 71.20. \pm b, 71.27. + a

\section{INTRODUCTION}

Semiconductor compounds $\mathrm{CdX}(\mathrm{X}=\mathrm{O}, \mathrm{S}, \mathrm{Se}, \mathrm{Te})$ have been attracting widespread scientific and technological interest due to their unique optical and electronic properties, as well as their potential applications in a wide variety of electronic devices. In particular, the CdO material has been intensively investigated as a potential candidate material for solar cells, smart windows, gas sensors, IR detectors and photodiodes, conducting electrodes, anti-reflection coatings and liquid crystal displays [1]. Also, it is widely used in biomedical applications [2].

The optoelectronic properties make cadmium sulphide (CdS) suitable especially as a window layer in solar cells when paired with absorbing materials such as CdTe [3].

Cadmium selenide (CdSe), a well-known direct bandgap II-VI semiconductor in which the bandgap favors absorption over a wide range of the visible spectrum, is a promising material for applications in such fields as photodetectors, field-effect transistors, field emitters, solar cells, light-emitting diodes, me-mory devices, biosensors, and biomedical imaging [4].

Cadmium telluride (CdTe) found widely used as a main material in the manufacture of highly sensitive uncooled detectors of gamma radiation [5], in production of low cost and high efficiency thin-film solar cells [6], as an element in solar thermal systems [7].

The band gap optimization of the CdTeSe thin-film solar cells has been carried out for the device modeling [8]. The review on the structural and substructural properties of the zinc and cadmium chalcogenides thin films has been done in a work [9]. Clusters of point defects near dislocations as a tool to control electrical parameters by ultrasound, in CdZnTe semiconductors, used for radiation detection, have been studied in a work [10].

The first-principle wave function obtained with the strong correlations of $4 d$ and $3 d$ electrons made it possible to obtain a very good comparison with the experiment of kinetic coefficients in the CdTe [11] and ZnSe [12] crystals.

The corrected band energies of the electrons are calculated according to a two-stage scheme "generalized gradient approximation [13] - Green's function [14]" (GGA-GW). It has proved effective in systems with $s(p)$ electrons [15]. However, in CdX crystals, due to the presence of strongly correlated $4 d$ electrons, localized in narrow energy bands, the GGA-GW approach is not effective. Therefore, we use the combination "hybrid functional - Green's function", that is the HSE06-GW [14].

\section{CALCULATION}

Hybrid functionals of the exchange-correlation energy take into account the presence of two electron subsystems in a crystal. An important point of their structure is the presentation of the nonlocal Coulomb potential by the sum of the long-range (LR) and short-range (SR) terms [16]:

\footnotetext{
*svsnpe@gmail.com
} 


$$
V(u)=V^{L R}(u)+V^{S R}(u),
$$

where $u=\left|\mathbf{r}-\mathbf{r}^{\prime}\right|$ is the distance between electrons. The simplest form of the exchange energy functional is as follows [17]:

$$
E_{x}^{P B E 0}=\alpha E_{x}^{H F}+(1-\alpha) E_{x}^{P B E},
$$

where the local electron component $E_{x}^{P B E}$, depending on $s(p)$ electron density [14], describes a weakly correlated system, and the nonlocal component, dependent on the wave functions of the $\mathrm{Cd} 4 d$ electrons, corresponds to the contribution of the exact Hartree-Fock potential.

Using in Eq. (2) the definition (1), neglecting the difference $\alpha E_{x}^{H F, L R}-\alpha E_{x}^{P B E, L R}$, and adding correlation energy results in the hybrid functional of the exchangecorrelation energy HSE [17]:

$$
E_{x c}^{H S E}=\alpha E_{x}^{H F, S R}+(1-\alpha) E_{x}^{P B E, S R}+E_{x}^{P B E, L R}+E_{c}^{P B E}
$$

The PBE0 hybrid functional (2), implemented in the ABINIT software package [14], is unscreened and leads to noticeable errors in the lattice parameter and band gap for a number of crystals [16]. The functional (3) avoids these drawbacks. In the ABINIT code, it is implemented on basis of the norm-conserving pseudopotentials [17]. The following section summarizes the results obtained within the GGA-PBE and HSE06-GW approaches corrected for the spin-orbit interaction.

\section{RESULTS AND DISCUSSION}

The electron energy bands of some CdX crystals, obtained with the GGA-PBE exchange-correlation potential, are shown in Fig. 1a, Fig. 3a, and Fig. 5a. The corresponding value of the mixing factor in Eq. (3) $\alpha=0$.

The electron energy bands, obtained within the HSE06-GW approach with default value of the factor $\alpha=0.25$, are shown in Fig. 1b, Fig. 3b, and Fig. 5b. We also did some more calculations with higher values of the $\alpha$ parameter. These results are presented in Fig. 1c, Fig. 3c, and Fig. 5c.

The energy parameters listed in Table 1-Table 4 denote a band gap $E_{g}$, the $E_{4 d}-E_{v a l}$ energy differences, and the width of the $4 d$ band $d E_{4 d}$ in CdX crystals at the point $\Gamma$ in the Brillouin zone (in $\mathrm{eV}$ ).

\subsection{Band Energies in CdO Wurtzite Crystal}

The electron energies in the CdO crystal evaluated with the GGA exchange-correlation functional are shown in Fig. 1a.

The maximum of the valence band $\varepsilon_{v}$ and the minimum of the conduction band $\varepsilon_{c}$ are denoted by $v$ and $c$, respectively. As can be seen from Fig. 1a, the GGA approach provides a zero-band gap. Fig. 1b, c shows the electron energy bands derived by combination of the HSE06 hybrid exchange-correlation functional (3) and quasiparticle GW approach. The electron energies depicted in Fig. 1c show the band gap equal to $0.90 \mathrm{eV}$, which is well compared with the experimental value. The dispersion curves represented in Fig. $1 b$ reveal the band gap of $1.00 \mathrm{eV}$, which is obtained with a default mixing factor $\alpha=0.25$ in Eq. (3). The $\mathrm{CdO}$ crystal has a direct optical and fundamental band gap at the $\Gamma$ point of the first Brillouin zone. The effect of the spin-orbit interaction on $\mathrm{Cd} 4 d$ electron energies can be observed from Fig. 2 indicating a significant effect of the SOC on the energy spectrum of semicore $4 d$ electrons. In case of the $\mathrm{CdO}$ crystal, SOC causes a small splitting of the states in the upper part of the valence band and also in the conduction band.

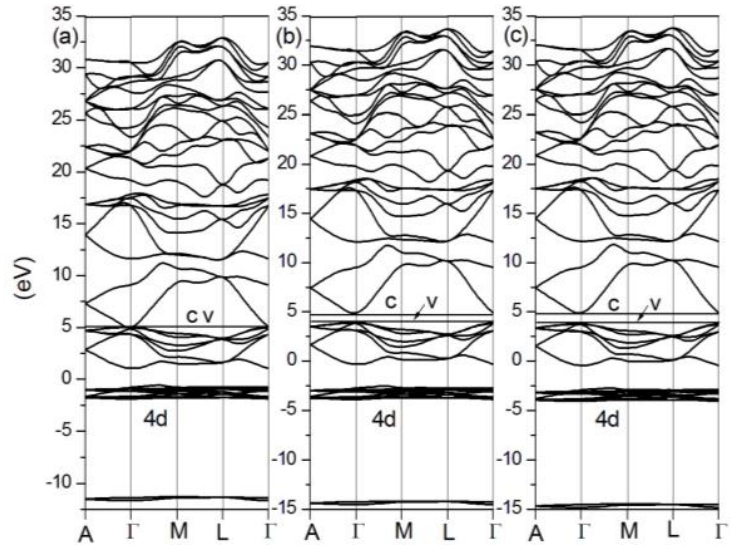

Fig. 1 - The band structure of the $\mathrm{CdO}$ crystal

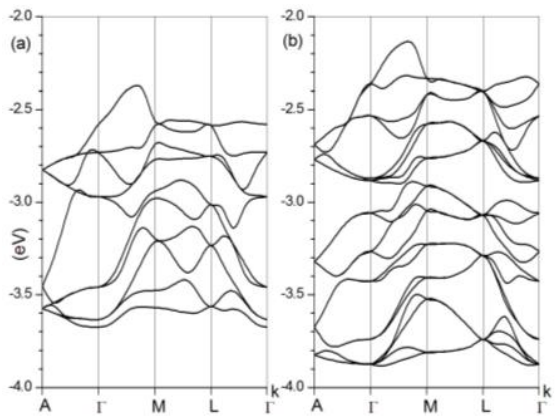

Fig. 2 - The electron energies of the semicore $4 d$ states in the CdO crystal: (a) without SOC, (b) with SOC

Table 1-Parameters of the electronic energy spectrum (in $\mathrm{eV}$ ) in the $\mathrm{CdO}$ crystal at the $\Gamma$ point in the $\mathrm{BZ}$

\begin{tabular}{|c|c|c|c|}
\hline & $E_{g}(\alpha)$ & $E_{4 d}-E_{v a l} \max$ & $d E_{4 d}$ \\
\hline PBE & $0.0(0.0)$ & -5.81 & 1.11 \\
\hline HSE GW & $1.00(0.25)$ & -6.62 & 1.14 \\
\hline HSE GW & $0.90(0.23)$ & -6.56 & 1.13 \\
\hline
\end{tabular}

As can be seen from Fig. 1 and from Table 1, the greater value of the mixing coefficient $\alpha$ corresponds to the lower energy of the $\mathrm{Cd} 4 d$ states in the valence band. An increase in the $\alpha$ coefficient means an increase in the fraction of the exact screened HartreeFock exchange potential in the functional of the exchange-correlation energy (3)

\subsection{Band Energies in CdS Wurtzite Crystal}

Fig. 3 shows that the crystal has a direct band gap at the $\Gamma$ point in the first Brillouin zone. The dispersion curves have been obtained with values of the mixing parameter of $0.0,0.25$, and 0.375 . The corresponding band gap values are equal to $1.48,2.19$, and $2.49 \mathrm{eV}$, respective- 
ly. The last calculated value of the band gap agrees very well with the measured one. Fig. 3 and data represented in Table 2 also show a decrease in the Cd $4 d$ levels, in the valence band, with an increase in the parameter $\alpha$.

The SOC affects the electronic energy spectrum of the upper part of the valence band and the conduction band to a small extent. Comparing Fig. $4 \mathrm{a}$ and Fig. 4b, we conclude that the dispersion curves of $\mathrm{Cd} 4 d$ electrons in the valence band are noticeably changed. The SOC leads to an increase in the energy interval of localization of $\mathrm{Cd} 4 d$ electrons by about $0.5 \mathrm{eV}$.

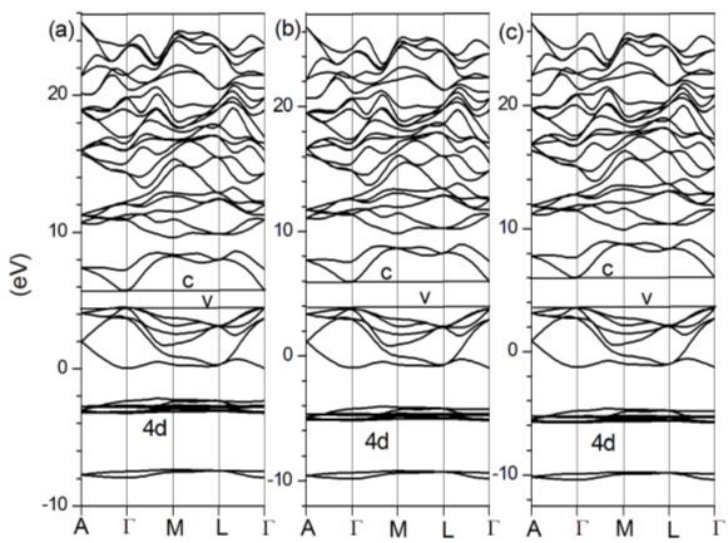

Fig. 3 - The band structure of the CdS crystal

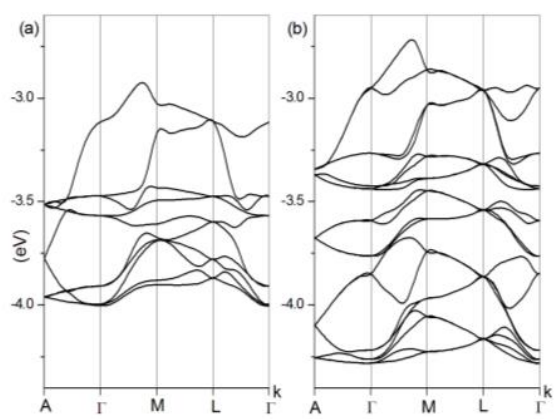

Fig. 4 - The electron energy bands in the CdS crystal: semicore $4 d$ states (a) without SOC, (b) with SOC

Table 2 - Parameters of the electronic energy spectrum (in $\mathrm{eV}$ ) in the CdS crystal at the $\Gamma$ point in the BZ

\begin{tabular}{|c|c|c|c|}
\hline & $E_{g}(\alpha)$ & $E_{4 d}-E_{v a l} \max$ & $d E_{4 d}$ \\
\hline PBE & $1.48(0.0)$ & -6.41 & 1.33 \\
\hline HSE GW & $2.19(0.25)$ & -8.92 & 0.71 \\
\hline HSE GW & $2.49(0.375)$ & -8.40 & 0.95 \\
\hline
\end{tabular}

\subsection{The Effect of the SOC on Band Energies in CdSe Crystal}

The crystal has a direct band gap at the $\Gamma$ point of the first Brillouin zone. The electronic band gaps, evaluated with the parameters $\alpha=0.0,0.25$ and 0.31 , are equal to $0.67,1.66$, and 1.92 , respectively.

The spin-orbit interaction causes a decrease in the band gap by $0.12 \mathrm{eV}$. Subtracting this value from the value of the band gap (Table 3), $1.92 \mathrm{eV}$, we obtain the direct gap of $1.80 \mathrm{eV}$, which is well compared with the experimental one (Table 5).

It is seen from the calculated electronic band energies and also from the data listed in Table 3 that the
Cd $4 d$ levels become deeper in the valence band when the parameter $\alpha$ increases. Comparing Fig.4a and Fig. $4 \mathrm{~b}$, we note that the SOC causes splitting of energy levels of $4 d$ electrons in the valence band.

We found that the SOC caused the partition of the band curves of the $\mathrm{Cd} 4 d$ states into two groups, with an energy gap between them.

Table 3 - Parameters of the electronic energy spectrum (in $\mathrm{eV}$ ) in the CdSe crystal at the $\Gamma$ point in the BZ

\begin{tabular}{|c|c|c|c|c|}
\hline & $E_{g}(\alpha)$ & $E_{g}$ soc & $E_{4 d}-E_{v a l} \max$ & $d E_{4 d}$ \\
\hline PBE & $0.67(0.0)$ & 0.55 & -7.26 & 0.67 \\
\hline HSE GW & $1.66(0.25)$ & 1.54 & -8.22 & 0.50 \\
\hline HSE GW & $1.92(0.31)$ & 1.80 & -8.53 & 0.72 \\
\hline
\end{tabular}

\subsection{Band Energies in CdTe Wurtzite Crystal Modified by Spin-orbit Coupling}

The electronic energy bands of the CdTe crystal are illustrated in Fig. 5. It is seen that the crystal has a direct band gap at the $\Gamma$ point in the first Brillouin zone. The electron energies were evaluated at values of the parameter $\alpha 0.0,0.25$, and 0.36 . The corresponding band gaps are equal to $0.84,1.69$, and $2.10 \mathrm{eV}$, respectively.

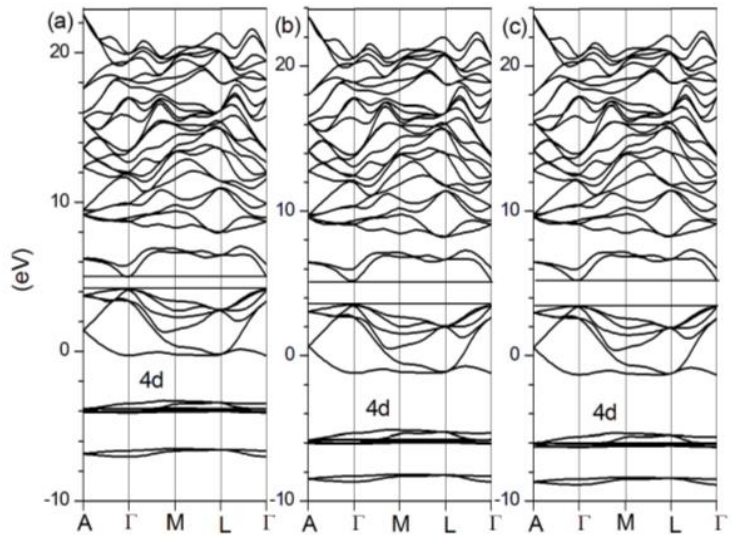

Fig. 5 - The band structure of the CdTe crystal

Table 4 - Parameters of the electronic energy spectrum (in $\mathrm{eV}$ ) in the CdTe crystal at the $\Gamma$ point in the BZ

\begin{tabular}{|c|c|c|c|c|}
\hline & $E_{g}(\alpha)$ & $E_{g}$ soc & $E_{4 d}-E_{v a l} \max$ & $d E_{4 d}$ \\
\hline PBE & $0.84(0.0)$ & 0.57 & -7.69 & 0.62 \\
\hline HSE GW & $1.69(0.25)$ & 1.42 & -8.86 & 0.71 \\
\hline HSE GW & $2.10(0.36)$ & 1.83 & -9.35 & 0.76 \\
\hline
\end{tabular}

We found that the spin-orbit narrowing of the band gap equals to $0.27 \mathrm{eV}$. Subtracting this value from the last band gap (Table 4), we obtain the direct band gap of $1.83 \mathrm{eV}$, which is well compared with the experimental value given in Table 5 .

Table 5 - The band gap values (in $\mathrm{eV}$ ) in $\mathrm{CdX}$ crystals obtained with other theoretical methods and found from experiment

\begin{tabular}{|l|c|c|c|c|}
\hline & CdO & CdS & CdSe & CdTe \\
\hline PBE [18] & 0.0 & 1.36 & 0.73 & 0.64 \\
\hline HSE [18] & $0.75,1.13$ & 2.15 & 1.77 & 1.6 \\
\hline SIRC [19] & & 2.5 & 1.3 & \\
\hline OEPx GW [20] & & 2.36 & & \\
\hline ACBN0 [18] & 1.23 & 2.4 & 1.61 & 1.33 \\
\hline Exper. [18] & 0.91 & 2.5 & 1.8 & $1.8(\mathrm{ZB})$ \\
\hline
\end{tabular}


The spin-orbit interaction causes band gap narrowing in the CdTe crystal more than in the CdSe material. The dispersion curves of $4 d$ electrons in the CdTe crystal are divided into two groups.

The results presented in Table 1-Table 4 indicate the noticeable impact of strong correlations of $\mathrm{Cd} 4 \mathrm{~d}$ electrons on the values of the band gaps for all $\mathrm{CdX}$ crystals. In fact, an increase in the mixing parameter $\alpha$ leads to a noticeable increase in the bandgap, and also contributes to the deepening of the $\mathrm{Cd} 4 d$ energy levels within the valence band.

The results presented in Table 5 show that none of the theoretical approaches is equally successful for CdX crystals considered here. For example, the HSE provides very good agreement with experimental $E_{g}$ only for the CdSe crystal, and the SIRC approach shows the best result for the CdS material. The new hybrid functional ACBNO is also successful in case of the CdS crystal.

The OEPx GW approach demands significant computing resources, so it has been applied so far to a small number of materials.

\section{CONCLUSIONS}

The electronic energy bands of CdX crystals in a wurtzite phase have been evaluated within the combined

\section{REFERENCES}

1. Ho Soonmin, Int. J. Curr. Adv. Res. 5, 1038 (2016)

2. S. Ghotekar, Asian J. Green Chem. 3, 187 (2019).

3. M.L. Madugu, L.U. Grema, A. Lawal, H.M. Ndahi, N.Y. Pindiga, Dutse, J. Pure Appl. Sci. 4, 592 (2018)

4. L. Zhao, L. Hu, X. Fang, Adv. Funct. Mater. 22, 1551 (2012).

5. D.V. Korbutyak, S.V. Melnychuk, O.V. Korbut, M.M. Borisyuk, Cadmium Telluride: impurity-defect states and detector properties (Kyiv: Ivan Fedorov: 2000) [in Ukrainian].

6. S.K. Sahoo, B. Manoharan, N. Sivakumar, In: Perovskite Photovoltaics (Eds. by S. Thomas, A. Thankappan) (Acad. Press. Ch. 1: 2018).

7. Y. Tripanagnostopoulos, In: Comprehensive Renewable Energy 3, 255 (Ed. A. Sayig) (Elsevier: 2012).

8. S. Meng, Y. Yan, J. Adv. Phys. 12, 4213 (2016)

9. C.J. Panchal, A.S. Opanasyuk, V.V. Kosyak, M.S. Desai, I.Yu. Protsenko, J. Nano- Electron. Phys. 3, 274 (2011).

10. Ya.M. Olikh, M.D. Tymochko, O.Ya. Olikh, V. A. Shenderovsky, J. Electron. Mater. 47, 4370 (2018).

11. O.P. Malyk, S.V. Syrotyuk, Comput. Mater. Sci. 139, 387 (2017).

12. O.P. Malyk, S.V. Syrotyuk, J. Electron. Mater. 47, 4212 (2018).

13. J.P. Perdew, K. Burke, M. Ernzerhof, Phys. Rev. Lett. 77, 3865 (1996). scheme HSE06-GW. The band gaps obtained within the GGA approach revealed very much underestimation compared with experiment. The results obtained here within the HSE06-GW approximation with the mixing coefficient $\alpha=0.25$ differ from the experimental values by 0.09 , $0.31,-0.26$, and $-0.11 \mathrm{eV}$ for $\mathrm{CdO}, \mathrm{CdS}, \mathrm{CdSe}$, and CdTe, respectively.

Better comparison with experiment is shown by the band gaps obtained with the third values of the mixing coefficients given in Table 1-Table 4. The corresponding differences are of about $0.01 \mathrm{eV}$.

The spin-orbit interaction can be neglected for $\mathrm{CdO}$ and CdS crystals. It causes narrowing of the band gap in CdSe and CdTe crystals by 0.12 and $0.27 \mathrm{eV}$, respectively. The spin-orbit coupling leads to significant reconstruction of $4 d$ bands. The localization intervals of the $4 d$ states in CdX crystals become much wider after inclusion of the SOC. In $\mathrm{CdO}$ and CdS crystals, the SOC causes splitting of the $4 d$ energy levels which shows much overlap in the valence band. However, in CdSe and CdTe crystals, $4 d$ bands are splitted into two groups separated by an energy window. The results obtained here allow us to draw attention to the issue of accuracy in the calculation of the optical constants of CdX crystals without taking into account the spin-orbit interaction.

14. X. Gonze, F. Jollet, F. Abreu Araujo, D. Adams, B. Amadon, T.Applencourt, C. Audouze, J.-M. Beuken, J. Bieder, A. Bokhanchuk, E.Bousquet, F. Bruneval, D. Caliste, M. Cote, F. Dahm, F. Da Pieve, M.Delaveau, M. Di Gennaro, B. Dorado, C. Espejo, G. Geneste, L.Genovese, A. Gerossier, M. Giantomassi, Y. Gillet, D.R. Hamann, L.He, G. Jomard, J. Laflamme Janssen, S. Le Roux, A. Levitt, A.Lherbier, F. Liu, I. Lukacevic, A. Martin, C. Martins, M.J.T. Oliveira,S. Poncè, Y. Pouillon, T. Rangel, G.-M. Rignanese, A.H. Romero, B.Rousseau, O. Rubel, A.A. Shukri, M. Stankovski, M. Torrent, M.J. VanSetten, B. Van Troeye, M.J. Verstraete, D. Waroquiers, J. Wiktor, B.Xu, A. Zhou, J.W. Zwanziger, Comput. Phys. Commun. 205, 106 (2016).

15. S.V. Syrotyuk, V.M. Shved, Yu.V. Klysko, Acta Phys. Pol. A 133, 990 (2018).

16. J. Heyd, G.E. Scuseria, J. Chem. Phys. 121, 1187 (2004)

17. K.F. Garrity, J.W. Bennett, K.M. Rabe, D. Vanderbilt, Comput. Mater. Sci. 81, 446 (2014).

18. P. Gopal, M. Fornari, S. Curtarolo, L.A. Agapito, L.S.I. Liyanage, M.B. Nardelli, Phys. Rev. B 91, 245202 (2015).

19. D. Vogel, P. Krüger, J. Pollmann, Phys. Rev. B 54, 5495 (1996).

20. P. Rinke, A. Qteish, J. Neugebauer, C. Freysoldt, M. Scheffler, New J. Phys. 7, 126 (2005) 


\title{
Вплив спін-орбітальної взаємодії на зонні енергії електронів, отримані у халькогенідах кадмію за комбінованим методом HSE06-GW
}

\author{
С.В. Сиротюк, О.П. Малик
}

Національний університет “Львівська політехніка”, вул. С. Бандери, 12, 79013 Львів, Украйна

\begin{abstract}
Розраховані електронні енергетичні спектри кристалів $\mathrm{CdX}(\mathrm{X}=\mathrm{O}, \mathrm{S}, \mathrm{Se}, \mathrm{Te})$ у вюрцитній фазі Виявлено, що $4 d$ електрони $\mathrm{Cd}$ локалізовані у вузьких смугах енергії валентної зони. Отримані нами результати показали, що розвинені у підходах LDA та GGA обмінно-кореляційні функціонали незастосовні до сильно корельованої підсистеми $4 d$ електронів $\mathrm{Cd}$. Справді, ширина забороненої зони, знайдена для кристала $\mathrm{CdO}$ у цих підходах, $E_{g}=0$, а її значення для матеріалів CdS, CdSe та CdTe дорівнюють $1,48,0,67$ та $0,84 \mathrm{eB}$, відповідно. Всі вони е значно меншими за виміряні $E_{g}$ для матеріалів CdX, які дорівнюють 0,$91 ; 2,5 ; 1,8$ та 1,8 еB відповідно. Ми виявили, що схема розрахунку “GGA функція Гріна", яка дуже ефективна для $s$ - $p$ електронних систем, не привела до успішних результатів для кристалів $\mathrm{CdX}$. Тому ми обрали поеднання підходів "гібридний функціонал - функція Гріна". Знайдені у кристалах $\mathrm{CdX}$ без урахування спін-орбітальної взаємодії значення $E_{g}$ дорівнюють 0,90 ;

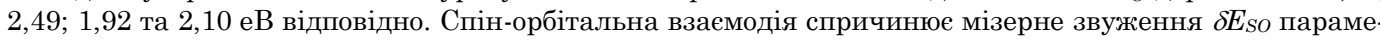
тра $E_{g}$ у кристалах $\mathrm{CdO}$ та CdS. Однак у матеріалах $\mathrm{CdSe}$ та CdTe значення параметра звуження $\delta E_{S O}$ дорівнюють 0,12 та $0,27 \mathrm{eB}$. Поправлені на $\delta E_{S O}$ ширини забороненої зони $E_{g}$ кристалів CdSe та $\mathrm{CdTe}$ набувають значень 1,80 та $1,83 \mathrm{eB}$. Отримані значення $E_{g}$ дуже добре зіставляються з експериментом. Знайдено, що енергетичні зони напівостовних $4 d$ електронів $\mathrm{Cd}$, отримані без урахування спінорбітальної взаємодії, перекриваються у кристалах $\mathrm{CdX}$. Спін-орбітальна взаємодія приводить до розширення смуг енергії, у яких локалізовані $4 d$ електрони Cd. Однак у кристалах CdSe та CdTe спінорбітальна взаємодія приводить до чіткого розділення енергетичних зон $4 d$ електронів на дві смуги, нижча з яких містить 8 , а вища - 12 гілок спектру.
\end{abstract}

Ключові слова: CdX, Структура вюрциту, HSE06, GW, Спін-орбітальна взаемодія. 